\title{
Role of leaf- and rhizosphere-associated bacteria in reducing air pollution of industrial cities in Saudi Arabia
}

\author{
M. A. Khiyami \\ General Directorate of Research Grants Programs, \\ Directorate of Research Follow-up, \\ King Abdulaziz City for Science and Technology, Riyadh, Saudi Arabia
}

\begin{abstract}
With the establishment of industrial cities such as Jubail and Yanbu, Saudi Arabia has been increasing its efforts to protect the country from various environmental hazards, several air quality monitors and meteorology network stations are operated throughout the kingdom to monitor parameters such as sulfur dioxide, ozone, nitrogen oxide, and hydrogen sulfide. As a result, air pollution in the Saudi cities is the lowest in the Middle East.

Microorganisms play a major role in removing pollutants from water, soil and air. Leaf- and rhizosphere-associated bacteria have an impact in reducing air pollution. Plant species growing in the industrial cites were studied by scanning electron microscopy (SEM) to observe the bacteria. Seventeen bacterial colonizations of leaves and rhizosphere were identified by API, biochemical tests, and PCR. The ability of the isolates to biodegrade different air and soil pollutants such as phenol, sulfate and nitrogen compounds was examined. Furthermore, the ability of leaf isolates to produce Extracellular polysaccharide (EPS) was examined.

Keywords: industrial cities, emission, pollutants, bacteria, rhizosphere, biodegradation, extracellular polysaccharide.
\end{abstract}

\section{Introduction}

Saudi Arabia is strategically located in the southwest corner of Asia, at the crossroads of Europe, Asia and Africa. Jubail and Yanbu are two major industrial cities in Saudi Arabia on the eastern and western coasts. The Royal 
Commission (RC), the administrator of the two cities promotes and encourages the investors in these areas to invest in various oil and petroleum-related activities and businesses including the manufacture of organic chemicals, fertilizers, plastics, and synthetic materials. The RC made a conscious decision to balance industrial productivity with environmental quality, capitalizing on the lessons learned from other countries.

Several early measures were implemented to protect the environment, including setting up standards, regulations, and design review criteria aimed at restricting industrial air emissions and effluent discharges to levels consistent with the best available control technologies. In the beginning, the RC established comprehensive programs in Jubail and Yanbu to monitor ambient and source factors influencing the environment. Also, the RC maintains environmental control units at Jubail and Yanbu. Staffed with environmental scientists, engineers and other specialists, these groups monitor and enforce the standards and regulations in the industrial cities. On the other hand, the RC operates a number of sophisticated air monitoring stations in Jubail and Yanbu to ensure and maintain that facilities meet national air quality standards. These stations record parameters such as sulfur dioxide, inhalable particulates, ozone, nitrogen oxides, carbon monoxide, and hydrogen sulfide.

Beside the sophisticated air monitoring stations operated in Jubail and Yanbu, the RC built a network of greenways surrounding the cities. These greenways become a great source for recreation, being used for activities such as fitness, walking, running, skating, and cycling. Furthermore, greenways serve as natural conservation from the evolving gases that might escape from the air quality filters in the factories.

Plant leaves are commonly colonized by large bacterial populations, as well as by other microorganisms including yeasts, mycelia fungi, and algae [4]. Each leaf has its own ecosystem - an ecosystem in which microorganisms: a) battle among themselves for limited resources; b) forge strategies for surviving making rapid changes in environmental conditions, and; c) actively change their own microenvironment by instigating changes in their host plant. Among the bacterial species found on leaves, some can induce disease, other can fix atmospheric nitrogen, and some can degrade airborne pollutants that have collected on the leaf surface. In most cases, the potential for bacteria to perform these functions depends on the size of bacteria population that survives the environmental conditions and its ability to colonization [5]. In this study we have isolated bacterial populations (Epiphytic and Endophytic bacteria) that colonize the leaves and rhizosphers of trees to define their role in reducing air and soil pollutants in industrial city of Yanbu in Saudi Arabia.

\section{Material and methods}

\subsection{Study location}

Yanbu is located on the red sea, about $350 \mathrm{~km}$ from Jeddah. Yanbu city occupies about $185 \mathrm{~km}^{2}$. Jubail and Yanbu industrial cities have established a range of 228 support industries and the infrastructure has provided encouragement to establish 
41 primary and 50 secondary industries. Most of these industrial units are oil refineries and petrochemicals. Jubail and Yanbu Industrial cities are surrounded by a network of greenways to protect the environment in the residential areas. Trees in the greenway were the target of this study to collect samples and isolates in an attempt to identify the bacteria that can degrade the evolving gases.

\subsection{Gases and particles in city sky}

Usually most of studies on air population in all cities report gases that include $\mathrm{SO} 2, \mathrm{NOx}, \mathrm{CO}, \mathrm{O} 3$ and carbon hydrogen compounds except $\mathrm{CH}_{4}[3]$. However, international studies reported the emission of numerous hydrocarbon gases from oil refinery and petrochemical complexes [7, 9, 15, 17]. A study funded by King Abdulaziz City for Science and Technology [4], conducted on air pollutants in Yanbu industrial city has reported the emission of gases from three different stations $[2,10]$, as shown in table 1 .

Table 1: Monthly mean pollution concentration for station 3 at Madinat Yanbu Al-Sinaiyah (units are microgram per cubic meter, except $\mathrm{CO})$.

\begin{tabular}{|l|l|l|l|l|l|l|l|l|}
\hline Month & $\mathrm{NO}_{x}$ & $\mathrm{NO}$ & $\mathrm{NO}_{2}$ & $\mathrm{SO}_{2}$ & $\mathrm{O}_{3}$ & $\mathrm{CO}^{*}$ & $\mathrm{THC}$ & $\mathrm{TSP}$ \\
\hline May 1981 & 40.9 & 14.8 & 32.3 & 40.1 & 62.6 & 1.1 & $\mathrm{DI}$ & $* * *$ \\
\hline June & 34.8 & 9.0 & 26.1 & 25.6 & 59.3 & 1.5 & 1198 & $* * *$ \\
\hline July & 16.4 & 3.1 & 13.4 & 4.2 & 62.3 & 0.9 & 1398 & $* * *$ \\
\hline August & 17.0 & 4.3 & 12.8 & 12.1 & 59.9 & 2.2 & 1048 & $153 * * *$ \\
\hline September & 51.5 & 11.2 & 40.3 & 27.3 & 39.2 & 1.3 & 1028 & 228 \\
\hline October & 35.8 & 14.4 & 22.1 & 34.3 & 29.9 & 1.0 & $\mathrm{DI}$ & 151 \\
\hline November & 26.6 & 11.8 & 28.8 & 27.4 & 37.8 & 1.2 & DI & 190 \\
\hline December & 29.0 & $\mathrm{DI}{ }^{* *}$ & $\mathrm{DI}$ & 21.4 & 32.3 & 1.3 & DI & 142 \\
\hline January & 15.9 & $\mathrm{DI}$ & $\mathrm{DI}$ & 12.7 & 44.2 & 1.0 & 1298 & 189 \\
\hline
\end{tabular}

* Milligrams per cubic meter

** DI- data insufficient

*** Particulate sampling began on August 26 


\subsection{Samples collation}

Leaves and soil samples were collected during the summer of 2006. The leaf samples were collected from different plants. The samples were kept in clean sacks. The soil samples were collected from the rhizosphere region at a depth of $5 \mathrm{~cm}$ below the soil surface. The samples were kept in clean sacks. All samples were stored at $4^{\circ} \mathrm{C}$ for chemical and microbiological analysis [3].

\subsection{Scanning electron microscopy (SEM) study}

Different parts of leaf trichomes at stomata and at the epidermal cell wall and the depressions in the cuticle, were scanned using SEM to isolate bacteria

\subsection{Bacterial isolation}

The leaf samples were cleaned from dust and individual leaves were placed in large tubes containing $20 \mathrm{ml}$ of $10 \mathrm{mM}$, pH 7.0 potassium phosphate buffer, sonicated for $7 \mathrm{~min}$, and vortexed vigorously [6]. Appropriate suspensions were prepared and plated on different media to estimate bacterial cell numbers. Each leaf was weighed to allow the bacterial population size to be normalized for the amount of leaf tissue.

For rhizosphers soil sample the dilution plate method, originally described by Johnson et al [13] was employed with some $\mathrm{pH}$ modification. Appropriate soil suspensions was prepared and plated on different media to estimate bacterial cell numbers.

\subsection{Bacterial identification}

The colonies and isolates were identified by morphological, Gram Stain and biochemical methods using the API 20 system. Finally the isolates were subjected to Rapid PCR and 16 sRNA, the work is still in progress.

\subsection{Degradation of air pollution}

For preliminary screening experiments aimed at testing the ability of isolates to degrade air pollution, the minimal medium contained $8.0 \mathrm{~g}$ of $\mathrm{NH}_{4} \mathrm{H}_{2} \mathrm{PO}_{4}, 0.2 \mathrm{~g}$ of yeast extract, $2.0 \mathrm{~g} \mathrm{~K}_{2} \mathrm{HPO}_{4}, 0.5 \mathrm{~g}$ of $\mathrm{MgSO}_{4} \cdot 7 \mathrm{H}_{2} \mathrm{O}, 0.5 \mathrm{~g}$ of $\mathrm{Na}_{2} \mathrm{SO}_{4}, 0.5 \mathrm{~g}$ of $\mathrm{NaCl}, 10 \mathrm{mg}$ of $\mathrm{ZnCl}_{2} \cdot 2 \mathrm{H}_{2} \mathrm{O}, 8.0 \mathrm{mg}$ of $\mathrm{MnSO}_{4} \cdot 7 \mathrm{H}_{2} \mathrm{O}, 10 \mathrm{mg}$ of $\mathrm{FeSO}_{4} \cdot 7 \mathrm{H}_{2} \mathrm{O}$, $50 \mathrm{mg}$ of $\mathrm{CaCl}_{2}$ and $1.5 \mathrm{~g} \%$ agar in 1 liter of distilled water. The media was autoclaved at $121^{\circ} \mathrm{C}$ for $15 \mathrm{~min}$ and after cooling different concentration of phenol $(10.0,20.0,30.0,40.0,50.0,70.0100 .0 \mathrm{mM})$ were added as filter sterilization. All isolates were screened to phenol degradation by inculcation on the plates with different phenol concentration and incubated at $30^{\circ} \mathrm{C}$ for 7 days. The ability of isolates to degrade phenolic compounds was also examined in a minimal medium and with high phenol concentrations including 100.0, 150.0, 200.0, 250.0, and 300.0 mM. The phenol degradation measured by phenolic assay is based on the oxidation of phenolate ion where ferric ions are reduced to the ferrous state which was detected by the formation of the Prussian blue complex $\left(\mathrm{Fe}_{4}\left[\mathrm{Fe}(\mathrm{CN})_{6}\right]_{3}\right)$ with a potassium ferricyanide-containing reagent [16]. 
The assay mixture contained $25 \mathrm{ml}$ of deionized water, $250 \mu \mathrm{l}$ of sample, $3 \mathrm{ml}$ of ferric chloride reagent and $3 \mathrm{ml}$ of potassium ferricyanide reagent. The sample absorbance was measured at $720 \mathrm{~nm}$. The phenolic contents in the samples were expressed as syringic acid equivalents $\left(10 \mu \mathrm{g} \mathrm{ml}^{-1}\right.$ gives $\mathrm{A}_{760}$ of $\left.0.377 / \mathrm{ml}\right)$ [1].

\subsection{Degradation of soil pollutant}

Pollutants may accumulate in soil, and these pollutants stimulate microbial proliferate. Heavy metals, nitrogen and sulfate accumulate and contaminate soil environments and encourage special microbial groups to proliferate. To observe the role of pollutants on soil and their chemical activity effect on the microbial community, an enrichment technique for the growth of sulfate and nitrogen fixation bacteria was employed [8]. The isolates from study locations were compared to the isolates from the control location, which was out of the study zone.

\subsection{Extracellular polysaccharide (EPS) production}

Bacteria may modify their environment by producing a layer of EPS on leaf surfaces. The ability of isolates to produce the EPS was examined by using Plastic Compost Support (PCS) to develop biofilm. The PCS was produced as described by Ho et al [12]. The PCS tubes were cut into small pieces. $10.0 \mathrm{~g}$ of PCS was autoclaved at $121^{\circ} \mathrm{C}$ for $15 \mathrm{~min}$ in a $250 \mathrm{ml}$ flask with distilled water. After PCS sterilized the distilled water it was removed aseptically and $100 \mathrm{ml}$ of the minimal medium with $10.0 \%$ glucose was added. The flasks were inculcated with $0.5 \mathrm{ml}$ of $620 \mathrm{Abs} 18 \mathrm{hr}$ isolates bacteria and incubated at $30^{\circ} \mathrm{C}$ for 7 days. The suspended cell biomass was measured indirectly by absorbance at $620 \mathrm{~nm}$. Gram staining was performed on suspended cell pellets obtained from centrifugation at $8816 \mathrm{x}$ g for $15 \mathrm{~min}$ at $4.0^{\circ} \mathrm{C}$ of spent culture medium and of the sand of stripped cells from PCS biofilm [14]. Also, the flow cytometer measurement was employed to determine the bacterial cells.

\section{Results and discussion}

Seventeen bacteria leaves and rhizosphere were isolated and identified from leaves and soil samples, however, conformation of bacteria identification is still in progress. Table 2 showed the pre-identification of the bacteria.

The phenol degradation experiment was performed to represent the degradation of volatile compounds, VOCs, fig. 1. Previous study showed that evolving VOCs were resulted from refineries and petrochemical complexes [9, 11]. The VOCs were measured by using Multivariate receptor modeling which was applied to hourly observations of total nonmethane organic carbon (TNMOC) and 54 hydrocarbon compounds from C-2 to C-9. It should be mentioned that "in spite of the best efforts of government and industry, the emissions from refineries and chemical plants are notoriously hard to determine. Most of the emissions are so-called fugitive emissions from leaking valves, pipes, or connectors, of which there are tens of thousands in a large facility" [11]. 
Table 2: $\quad$ Bacterial strain isolated and pre-identified from leave and soil.

\begin{tabular}{|c|l|l|}
\hline No & \multicolumn{1}{|c|}{ Bacteria } & \multicolumn{1}{|c|}{ Source } \\
\hline 1 & Pseudomonas $\mathrm{sp}_{1}$ & Leaf \\
\hline 2 & Pseudomonas $\mathrm{sp}_{2}$ & Leaf \\
\hline 3 & Pseudomonas $\mathrm{sp}_{3}$ & Leaf \\
\hline 4 & Pseudomonas $\mathrm{sp}_{4}$ & Leaf \\
\hline 5 & Erwinia $\mathrm{sp}$ & Leaf \\
\hline 6 & Thiobacillus $\mathrm{sp}_{1}$ & rhizosphere \\
\hline 7 & Thiobacillus $\mathrm{sp}_{2}$ & rhizosphere \\
\hline 8 & Thiobacillus $\mathrm{sp}_{3}$ & rhizosphere \\
\hline 9 & Thiobacillus $\mathrm{sp}_{4}$ & rhizosphere \\
\hline 10 & Thiobacillus $\mathrm{sp}_{5}$ & rhizosphere \\
\hline 11 & Thiobacillus $\mathrm{sp}_{6}$ & rhizosphere \\
\hline 12 & Nitrobacter $\mathrm{sp}_{1}$ & rhizosphere \\
\hline 13 & Nitrobacter $\mathrm{sp}_{2}$ & rhizosphere \\
\hline 14 & Azatobacter $\mathrm{sp}$ & rhizosphere \\
\hline 15 & Rhizobium $\mathrm{sp}_{1}$ & rhizosphere \\
\hline 16 & Rhizobium $\mathrm{sp}_{2}$ & rhizosphere \\
\hline 17 & Rhizobium $\mathrm{sp}_{3}$ & rhizosphere \\
\hline
\end{tabular}
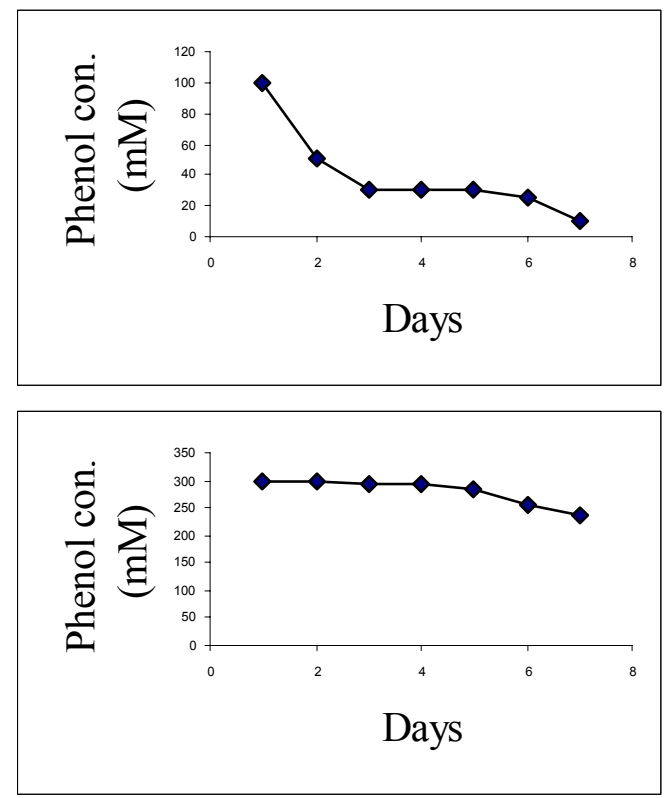

Figure 1: Degradation of different phenol concentration, 100 and $300 \mathrm{mM}$ by Pseudomonas $\mathrm{sp}_{2}$. 
The ability of bacterial rhizosphere to degrade the air pollution that accumulates in soil in the form of nitrogen and sulfate compounds was determined by isolating the sulfate reducing-oxidizing bacteria and nitrogen fixation bacteria. The formation of elemental sulfur and various other higher oxidation states of sulfur by microbial oxidation of more reduced forms of sulfur is a common activity in nature. There are a variety of types of microorganisms capable of such activities including chemoautotrophs, chemoheterotrophs, and photoautotrophs. Nitrification and symbiotic nitrogen fixation are especially sensitive to disruption by pollutants, probably in part due to the small numbers of species involved in these processes. In this study, the increment of bacteria that metabolized sulfur and nitrogen compounds was used as an indicator for contamination of soil by the sulfur or nitrogen compounds evolving from oil refinery and other petrochemical units. The results showed that total numbers of sulfate and nitrogen bacteria were high compared to the total bacterial count in the control location, see fig. 2.

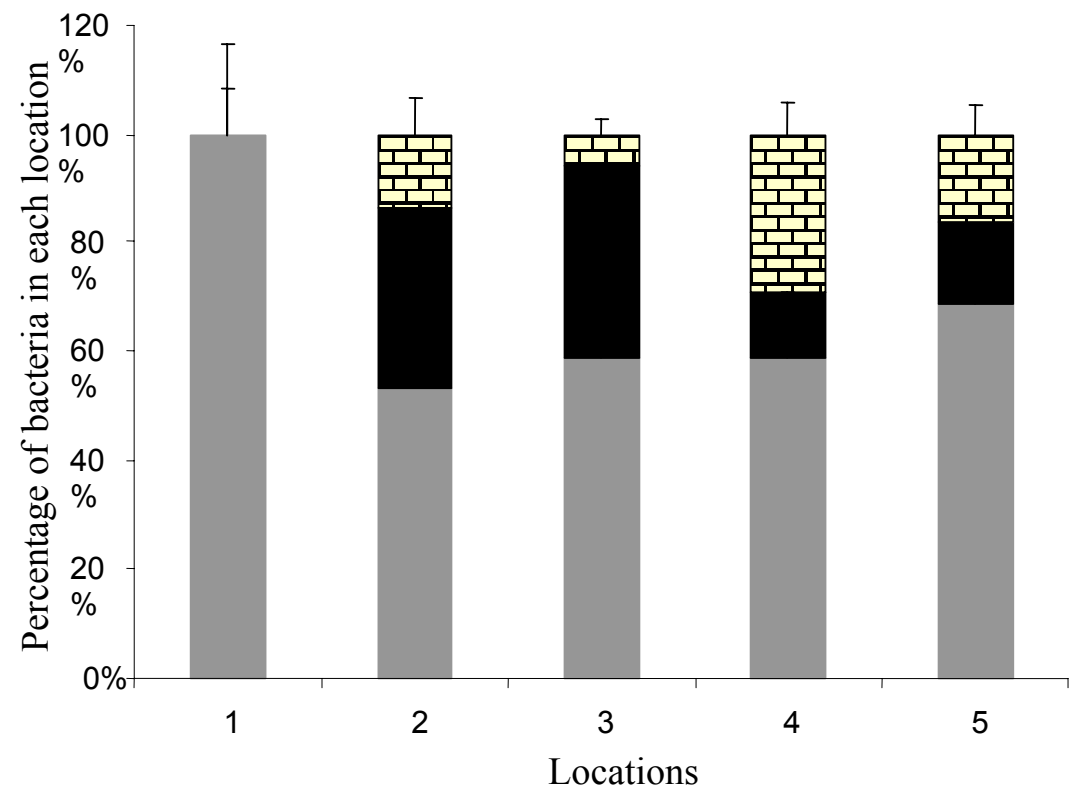

Total count of

Sulfate reducing

口Nitrogen fixation

Figure 2: $\quad$ The percentage of sulfate reducing and nitrogen fixation bacteria to the total count bacteria in five different locations.

The ability of leaf surface isolates to produce the EPS was examined. Two out of five bacteria showed the ability to produce EPS. Pseudomonas $\mathrm{sp}_{3}$ and Pseudomonas $\mathrm{sp}_{4}$ could grow on PCS within 7 days and CFU were $2.5 \times 10^{-5}$ and $2.1 \times 10^{-6}$ respectively. 


\section{Conclusions}

In spite of the efforts of the Royal Commission the emissions from refineries and chemical factories are notoriously hard to determine. Greenways around the industrial cities seem to serves as natural conservation from the gases that might escape from the air filters in the factories. Leaf and rhizosphere associated bacteria play a significant role in removing the pollutants. However, not all kinds of trees can develop leaf and rhizosphere associated bacteria, and it is important to select appropriate plants for industrial cities.

\section{References}

[1] Aggelis, G., Ehaliotis, C., Nerud, F., Stoychev, I., Lyberatos, G., \& Zervakis, G. Evaluation of white-rot fungi for detoxification and decolorization of effluents from the green olive debittering process. Appl. Microbial. Biotechnol, 59, pp. 353-360, 2002.

[2] Al-Radady, A. Study of air pollutants and their effects on the environmental and public health in the Yanbu Industrial City, Project funded by King Abdulaziz City for Science and Technology, Final report, AR-15-26, 2006.

[3] Al-senosy, I., \& Al-nashmi M. kind of air emission in Riyadh city and evaluation methods to reduce gases emission. Develop and effect on environment, conference in Riyadh city, Saudi Arabia, 1998.

[4] Beattie, G. A. \& Lindow, S. Bacterial colonization of leaves: A spectrum of strategies. Phytopathology, 89, pp. 353-359, 1999.

[5] Beattie, www.plantpath.iastate.edu/people/beattie

[6] Brandl, M. T. \& Lindow, S. E. Contribution of Indole-3-Acetic Acid Production to the Epiphytic Fitness of Erwinia herbicola. Appl. Environ. Micro. 64, pp. 3256-3263, 1998.

[7] Byers, R. L., Crocker, B. B., \& Cooper, D. W. Dispersion and control of atmospheric emission New-Energy-Source pollution potential Engineers, New York, 1997.

[8] Cooper, R. Jenkins, D. \& Young, L. Aquatic microbiology laboratory manual. University of California, Berkeley. 1976.

[9] DeLuchi, M. A., Emission from the production, storage, and transport of crude oil and gasoline. J. Air and West Mange. Assoc, 43, pp. 1486-14995, 1993.

[10] Ecology and Environment of Saudi Arabia Co. Ltd. (EESAL). Final report. Environmental monitoring program at Madinat Ynabu Al-Sinaiyah, prepared for the Royal Commission for Jubail and Ynbau under contract GST E-4021, 1984.

[11] Henry, R. Spiegelman, C.Collins, J. \& Park, E. Reported emissions of organic gases are not consistent with observations. Proc.Natl.Acad.Sci., 94, pp. 6596-6599, 1997.

[12] Ho, K., Pometto III, A., Hinz, P., Dickson, N., J. \& Demirci, A. Ingredient selection for plastic composite supports for $\mathrm{L}^{-(+)}$-lactic acid biofilm 
fermentation by Lactobacillus casei subsp. rhamnosus. Appl. Environ. Microbiol, 63, pp. 2516-2523, 1997.

[13] Johanson, L. E., Curl, E. A., Bond, J. H., \& Fribourg, H. A. Methods for studying soil microflora plant disease relationship. Burgess Publ. Co. Minn. USA. 1959.

[14] Ping-Shing, M. Isolation and characterization of thermophilic and hyperthermophilic microorganisms from food processing facilities. Thesis at Iowa State University, Ames, 2003.

[15] Sax, N. I., Industrial pollution, Van Nostrand Reinhold, New York, 1974.

[16] Waterman, P., \& Mole, S. Analysis of phenolic plant metabolites. (ed.), Methods in ecology: J. H. Lawton \& G. E. Likens Blackwell Scientific, Oxford. 1994.

[17] WHO, Rapid assessment of source of air, water and land pollution (WHO), Publisher, WHO, offset publication, 62, Geneva, 1982. 